\title{
1 Response of different soil organic matter pools to biochar and organic
}

\section{fertilizers}

3

4 César Plaza ${ }^{\text {a, * }}$, Beatrice Giannetta ${ }^{\text {b }}$, José M. Fernández ${ }^{\text {a }}$, Esther G. López-de-Sá ${ }^{a}$,

$5 \quad$ Alfredo Polo ${ }^{\mathrm{a}}$, Gabriel Gascó ${ }^{\mathrm{c}}$, Ana Méndez ${ }^{\mathrm{d}}$, Claudio Zaccone ${ }^{\mathrm{b}}$

6

7 a Instituto de Ciencias Agrarias, Consejo Superior de Investigaciones Científicas,

8 Serrano 115 bis, 28006 Madrid, Spain

9 b Department of the Sciences of Agriculture, Food and Environment, University of

10 Foggia, via Napoli 25, 71121 Foggia, Italy

11 c Departamento de Producción Agraria, ETSI Agrónomos, Universidad Politécnica de

12 Madrid, Ciudad Universitaria, 28040 Madrid, Spain

13 d Departamento de Ingeniería Geológica y Minera, ETSI Minas y Energía, Universidad

14 Politécnica de Madrid, Ríos Rosas 21, 28003 Madrid, Spain

15

$16{ }^{*}$ Corresponding author. Tel.: +34 917452500 Ext. 950191

17 E-mail address: cesar.plaza@csic.es (C. Plaza). 


\section{Highlights}

- Biochar enhances C stabilization in soils treated with organic fertilizers.

- Biochar promotes sorption of $\mathrm{C}$ on mineral surfaces in organically-fertilized soils.

- Biochar accumulates in the free organic matter pool not protected by the soil mineral matrix

- Biochar has little impact on mineral-associated organic matter composition. 
Abstract

A full understanding of the agronomic and environmental potential of biochar, and especially its potential as a $\mathrm{C}$ sequestration strategy, requires a full comprehension of its effects on native soil organic matter (SOM), as well as of its interactions with other organic amendments co-applied to the soil. In a field experiment, we investigated changes in quantity and quality of SOM pools characterized by different protection mechanisms as affected by $20 \mathrm{t} \mathrm{ha}^{-1}$ of biochar added alone or combined with two different organic fertilizers (i.e., municipal solid waste compost and sewage sludge) 8 months after application. In particular, free, intra-macroaggregate, intra-microaggregate, and mineral-associated SOM fractions were separated and analyzed for organic $\mathrm{C}$, total $\mathrm{N}$, and stable isotopic ratios; further, diffuse reflectance infrared Fourier transform spectroscopy was used to examine functional group composition. Soil biomass $\mathrm{C}$ content, basal respiration, and metabolic quotient were also determined. Biochar and organic fertilizer application increased significantly SOM content. Biochar accumulated mainly in the free SOM pool, not protected by the soil mineral matrix. Especially noteworthy was the significant interaction effect found between the biochar and organic fertilizer factors on mineral-associated organic $\mathrm{C}$ content. This suggested a promoting action of biochar on $\mathrm{C}$ stabilization in organically-fertilized soils through the formation of organo-mineral complexes. Organically-fertilized soils had higher microbial $\mathrm{C}$ than unfertilized soils. Basal respiration and metabolic quotient, however, were not affected by any of the treatments. As a whole, our results support the potential of biochar application as a strategy to sequester $\mathrm{C}$ in soils.

Keywords: Biochar; Microbial biomass C; Municipal solid waste compost; Physical fractionation; Sewage sludge; Soil respiration; Stable isotopes 


\section{Introduction}

Biochar is a C-rich product made by the pyrolysis of biomass (e.g., plant-derived biomass), with the intention of climate change mitigation and soil quality enhancement (e.g., Lehmann and Joseph, 2015). In particular, C in biochar is believed to form very stable structures, which can be stored in soils for much longer than the biomass $\mathrm{C}$ from which it originates, thus helping to fight global warming. Other benefits of soil application of biochar have been reported to include increased water and nutrient retention, increased cation-exchange capacity, correction of soil acidity, habitat for soil microbes, and control of plant pathogens, among others (e.g., Lehmann, 2007; Masiello et al., 2013; Lehmann and Joseph, 2015).

In spite of potential environmental and agricultural benefits of biochar application, there are still many open questions about its potential deleterious effects (Cernansky, 2015). In particular, some studies have found that biochar may increase mineralization rates of native soil organic matter (SOM). For example, Wardle et al. (2008) found that applying biochar stimulated soil microbial activity and loss of boreal forest humus over a 10-year period. Similarly, Luo et al. (2011) and Singh and Cowie (2014) reported positive priming effects of biochar on native SOM in incubation experiments. On the other hand, there are also studies in the literature showing no effects or even negative priming effects (Liang et al., 2010; Cross and Sohi, 2011; Jones et al., 2011; Lu et al., 2014; Weng et al., 2015). According to Zimmerman et al. (2011), differences in the magnitude and sign of the priming effect hinges on soil and biochar type, such that SOM mineralization tends to be stimulated in soils with low $\mathrm{C}$ content treated with biochars produced at low temperatures from grasses instead of woods.

For given climatic and environmental conditions, the interacting mechanisms that 
protect organic matter in the soil from mineralization conceptually include (a) selective preservation and synthesis of recalcitrant structures, (b) physical disconnection from decomposers, microbial enzymes, and $\mathrm{O}_{2}$ by inclusion within macro and microaggregates, and (c) inaccessibility by chemical association with mineral surfaces (e.g., Piccolo, 2001; Six et al., 2002a; von Lützow et al., 2006; Schnitzer and Monreal, 2011, Courtier-Murias et al., 2013; Plaza et al., 2013). Despite much effort over the past years, the processes and mechanisms contributing to organic matter stabilization and destabilization in soils treated with biochar remain largely unknown. Particularly little attention has been devoted to the interaction of biochar with other products used in agriculture to ameliorate soil fertility. Biochar is a recalcitrant material potentially suited to enhance $\mathrm{C}$ sequestration in soils, with much slower rates of decomposition than other organic amendments (e.g., Bolan et al., 2012), but not a significant source of plant nutrients. Thus, biochar application in combination with organic fertilizers is believed to be a promising strategy to improve its benefits on soil quality and crop yields (Ngo et al., 2013, 2014).

The objectives of this work were to (a) investigate the effects of biochar on SOM pools linked to conceptual stabilization mechanisms and (b) examine whether biochar interferes with the stabilization of organic $\mathrm{C}$ provided with two different organic fertilizers (i.e., municipal solid waste compost and sewage sludge) co-applied to the soil. Our hypothesis was that biochar would affect the quality and quantity of native SOM and the stabilization mechanisms of organic matter in fertilized soils, mainly through changes in soil microbial growth and activity.

\section{Materials and methods}



$\left(40^{\circ} 19^{\prime} \mathrm{N}, 3^{\circ} 29^{\prime} \mathrm{W}, 534 \mathrm{~m}\right.$ above sea level). The site was characterized by a Mediterranean climate, with an average annual rainfall of $436 \mathrm{~mm}$ and average annual temperature of $14{ }^{\circ} \mathrm{C}$. The soil showed a clay loam texture and was classified as a Xerofluvent (Soil Survey Staff, 2014). The biochar used in this study was produced in a pyrolysis plant from holm oak (Quercus ilex L.) chips through a slow pyrolysis process at $600{ }^{\circ} \mathrm{C}$. The municipal solid waste compost was produced using a conventional windrow composting system at a waste treatment plant. The sewage sludge consists of the granular end-product obtained by heat drying urban wastewater solids at about 75 ${ }^{\circ} \mathrm{C}$ at a wastewater treatment facility. The main properties of the top soil $(0-15 \mathrm{~cm})$, are summarized here in Table 1.

\subsection{Field experiment and soil sampling}

The experiment was set up as a randomized complete block design with two factors, namely biochar and organic fertilizer, with four replicates. In particular, a control treatment (no biochar) and a biochar application at a rate of $20 \mathrm{t} \mathrm{ha}^{-1}$ were combined with no organic fertilization, municipal solid waste compost at a rate equivalent to $75 \mathrm{~kg}$

117 potentially available $\mathrm{N}$ (PAN) ha ${ }^{-1}$, and sewage sludge at a rate equivalent to $75 \mathrm{~kg}$ PAN $118 \mathrm{ha}^{-1}$. All plots $\left(5 \times 3 \mathrm{~m}^{2}\right)$ were planted with winter barley (Hordeum Vulgare L.) in mid- 
119 November 2012. Biochar and organic fertilizers were hand broadcast in late October

1202012 and immediately incorporated into the upper $15 \mathrm{~cm}$ of soil with a rotary tiller. The

121 rate of biochar used in this study can be considered medium (Jeffery et al., 2011),

122 whereas the rate of organic fertilizer was selected to meet the annual $\mathrm{N}$ needs of the 123 crop.

124 Barley was harvested in late June 2013. A two-way analysis of variance (ANOVA) 125 revealed a significant effect of organic fertilization on aboveground biomass $(p<0.05)$, 126 such that yields were significantly higher by 27 and $8 \%$ on the soils treated with sewage 127 sludge and municipal solid waste compost than on the unfertilized soils. There were no 128 main or interaction effects of biochar on aboveground biomass. Main and interaction 129 effects of biochar and organic fertilization on grain yield were not significant (Moreno130 Jiménez et al., 2016).

131 Just after barley harvest, soil samples representative of the plow layer $(0-15-\mathrm{cm}$ 132 depth) were collected randomly from each plot. As common in the study area, soils 133 were dry at the time of sampling. The soil samples were gently crushed and passed 134 through a 2-mm sieve for physical fractionation and microbiological analysis. An 135 aliquot of each sieved sample was ground with a ball mill for organic $\mathrm{C}$ and total $\mathrm{N}$ 136 analyses.

\subsection{Physical fractionation of soil organic matter}

Free, intra-macroaggregate, intra-microaggregate, and mineral-associated SOM were separated using the method described by Plaza et al. (2012) with modifications detailed by Plaza et al. (2013). This method is based on the densimetric procedure of 143 Golchin et al. (1994) and Sohi et al. (2001) for the fractionation of free and occluded 
144 SOM and the method of Six et al. $(2000,2002 b)$ for the breakup of macroaggregates 145 preserving microaggregates. In brief, the free organic matter in $20 \mathrm{~g}$ of $2-\mathrm{mm}$ sieved soil 146 was separated by density flotation in a NaI solution (density, $1.85 \mathrm{~g} \mathrm{~mL}^{-1}$ ) and 147 subsequent suction and filtration. The macroaggregates in the remaining soil were 148 broken up using the microaggregate isolator device developed by Six et al. (2000, $1492002 b)$ for liberating intra-macroaggregate organic matter, which was then recovered by 150 a second density separation. Finally, the intra-microaggregate organic matter was 151 isolated from the mineral-associated organic matter fraction by a third density 152 separation after ultrasonic disruption (energy input, $1500 \mathrm{~J} \mathrm{~g}^{-1}$ ). Here NaI was used for 153 density separations instead of sodium polytungstate as reported in Plaza et al. (2012, 154 2013), because sodium polytungstate may contain some $\mathrm{N}$ that inevitably remains in the 155 heavy fraction after the last separation and hampers the examination of $\mathrm{N}$ distribution. 156 The recovered free, intra-macroaggregate, intra-microaggregate, and mineral-associated 157 organic matter fractions were oven-dried at $70^{\circ} \mathrm{C}$, weighed, and ground with a ball mill.

\subsection{Organic $C$, total $N, \delta^{13} C, \delta^{15} N$, and infrared analysis} matter fractions were determined by dry combustion with a Thermo Flash 2000 NC Soil Analyzer. Isotopic ratios $\left({ }^{13} \mathrm{C} /{ }^{12} \mathrm{C}\right.$ and $\left.{ }^{15} \mathrm{~N} /{ }^{14} \mathrm{~N}\right)$ of biochar, municipal solid waste 164 compost, unfertilized and compost-fertilized soils with or without biochar, and corresponding SOM fractions were determined in laboratory duplicates using an isotopic ratio mass spectrometer (IRMS, Finnigan Delta V Advantage, Thermo Fisher

167 Scientific) coupled with an elemental analyzer (FlashEA 1112 HT, Thermo Fisher 168 Scientific). The elemental analyzer was equipped with a PorapackQS gas 
169 chromatography column and connected to the IRMS through a Conflo III (Thermo

170 Fisher Scientific) interphase. The isotopic ratios were expressed in $\delta(\%)$ vs. V-PDB

171 (Vienna-Pee Dee Belemnite) for C and AIR (atmospheric $\mathrm{N}_{2}$ ) for N. For each run, at 172 least one in-house standard was analyzed to check the accuracy of the analysis. The 173 precision of measurements was usually $\pm 0.2 \%$ for $\delta^{13} \mathrm{C}$ and $\pm 0.3 \%$ o for $\delta^{15} \mathrm{~N}$. For 174 organic $\mathrm{C}$ and $\delta^{13} \mathrm{C}$ determination, the whole soil samples and mineral-associated 175 organic matter fractions were subjected to acid fumigation (Harris et al., 2001) before 176 the analysis to remove carbonates.

177 Diffuse reflectance infrared Fourier transform (DRIFT) spectra of biochar, 178 conventional amendments, soils, and SOM fractions were recorded using a Shimadzu 179 FTIR-8400 spectrophotometer on powdered mixtures of $20 \mathrm{mg}$ of sample and $200 \mathrm{mg}$ 180 of $\mathrm{KBr}$. The resolution was set at $4 \mathrm{~cm}^{-1}$. For each determination, 128 scans were 181 recorded over the range of 4000 to $400 \mathrm{~cm}^{-1}$, averaged, and corrected using $\mathrm{KBr}$ for the 182 background reference.

\subsection{Microbiological analysis}

Soil microbial biomass $\mathrm{C}$ was determined by the fumigation-extraction method of Vance et al. (1987) after aerobic pre-incubation for $24 \mathrm{~h}$ at $25{ }^{\circ} \mathrm{C}$ and $40 \%$ of water holding capacity. Basal respiration was determined by measuring the cumulative amount of $\mathrm{CO}_{2}$ that evolved and trapped in $\mathrm{NaOH}$ vials during the incubation of $50 \mathrm{~g}$ of soil at $40 \%$ of water holding capacity in a $1-\mathrm{L}$ jar for 14 days at $25{ }^{\circ} \mathrm{C}$. Metabolic quotient was calculated as the ratio of basal respiration to microbial biomass $\mathrm{C}$. 
Data were subjected to two- and one-way ANOVA. Treatment means were separated using Fisher's LSD test at the 0.05 level. R statistical software, version 3.1.1

197 (R Core Team, 2014), and the R package agricolae, version 1.2-0 (De Mendiburu, 2014), were used for data analysis.

\subsection{Organic $C$, total $N$, and isotopic signatures}

204 contents are significantly higher for biochar-treated soils (Figs. 1 and 2). In a laboratory

217 incubation study, Herath et al. (2014) also recovered most biochar C in the free organic 218 matte fraction. Similarly, organic fertilization significantly affects free $\mathrm{N}$ contents 
219 (Table 2), such that fertilized soils exhibit larger values than the unamended soils (Fig.

220 2). In a field experiment, Fernández et al. (2014b) found most $\mathrm{C}$ and $\mathrm{N}$ supplied with

221 organic fertilizers (municipal solid waste compost, sewage sludge compost, and

222 thermally dried sewage sludge) in the physically unprotected free organic matter pool.

223 They also found no organic matter accumulation in the intra-microaggregate and

224 mineral-associated pools after three years of annual application. Here the interaction

225 effects of biochar and organic fertilization on the soil organic $\mathrm{C}$ and $\mathrm{N}$ pools examined

226 are not significant, except for the mineral-associated fraction (Table 2). In particular,

227 only in the biochar-treated soils, organic fertilizers significantly increase the mineral-

228 associated organic $\mathrm{C}$ pool with respect to the controls (Fig. 1). Based on incubations of

229 biochar alone or mixed with organic fertilizers, with no soil, Ngo et al. (2013) suggested

230 that the presence of biochar could lead to a protection of exogenous organic matter

231 against chemical oxidation and biological degradation; in a subsequent field study, Ngo

232 et al. (2016) showed that mixing of biochar with organic fertilizers in litterbags on the

233 surface of a degraded Acrisol reduced C loss under tropical conditions. Our results

234 provide evidence that biochar can promote $\mathrm{C}$ stabilization in organically-fertilized soils

235 through the formation of organo-mineral complexes by intimate interaction between

236 mineral particles and organic inputs. The lack of interaction effect between the biochar

237 and organic fertilization factors on aboveground barley biomass suggests that, relative

238 to organic-fertilizer-derived inputs, plant-derived organic inputs may play a secondary

239 role in the stabilization mechanisms observed here.

240 The two-way analysis of variance shows significant main effects of biochar on the

$241 \mathrm{C} / \mathrm{N}$ ratio of whole soil and free, intra-macoraggregate, and intra-microaggregate

242 organic matter fractions (Table 2), with greater values for biochar-treated soils (Fig. 3).

243 Organic fertilization significantly decreases free, intra-macoraggregate, and intra- 
244 microaggregate $\mathrm{C} / \mathrm{N}$ ratios (Fig. 3). The interaction between the two factors is 245 significant for free and mineral-associated $\mathrm{C} / \mathrm{N}$. For the biochar-treated soils, the $\mathrm{C} / \mathrm{N}$ 246 ratio of the free organic matter is lower for the organically-fertilized soils than for the 247 unfertilized soil, whereas no organic fertilization effects are observed for the soils 248 without biochar. By contrast, the mineral-associated $\mathrm{C} / \mathrm{N}$ ratio of the soils without 249 biochar decreases with the application of the organic fertilizers, whereas no effects are 250 observed for the biochar-treated soils.

251 The $\delta^{13} \mathrm{C}$ and $\delta^{15} \mathrm{~N}$ of biochar, municipal solid waste compost, whole soils and the 252 corresponding SOM fractions are shown in Table 4. The $\delta^{13} \mathrm{C}$ of biochar and compost 253 are very similar to each other (-26.65 and $-25.13 \%$, respectively), thus resulting in no 254 clear trends in its signature either among whole soils or among SOM fractions. In 255 contrast, biochar and compost show markedly different $\delta^{15} \mathrm{~N}$ signatures $(2.32$ and $2566.63 \%$, respectively), which are also different from that of the untreated soil $(7.79 \%$ ). 257 As a consequence, the whole soil $\delta^{15} \mathrm{~N}$ signature decreases with both biochar and compost application. Furthermore, only the $\delta^{15} \mathrm{~N}$ signature of free SOM is strongly affected by biochar application, which indicates a preferential incorporation of biochar into this fraction. This influence is less evident for the intra-macroaggregate SOM fraction, whereas the intra-microaggregate and mineral-associated fractions seem to be unaffected. A similar behavior is observed after the application of compost and biochar with compost (Table 4).

Significant correlations $\left(R^{2}>0.82, p<0.05\right)$ are found between the $\delta^{13} \mathrm{C}$ and $\delta^{15} \mathrm{~N}$ of all SOM fractions separated from the untreated soil and the corresponding $\mathrm{C} / \mathrm{N}$ ratios. In particular, free $\mathrm{SOM}$ shows the highest $\delta^{13} \mathrm{C}$, the highest $\mathrm{C} / \mathrm{N}$ ratio and the lowest $\delta^{15} \mathrm{~N}(-23.34 \%$, 19.3 and $4.76 \%$ respectively); by contrast, mineral-associated SOM shows the lowest $\delta^{13} \mathrm{C}$, the lowest $\mathrm{C} / \mathrm{N}$ ratio, and the highest $\delta^{15} \mathrm{~N}(-25.25 \%$, 6.1 and 
$2698.34 \%$ respectively) (Fig. 4). Soil organic matter degradation may result in ${ }^{13} \mathrm{C}$ -

270 enrichment because bacteria preferentially metabolize ${ }^{12} \mathrm{C}$-rich compounds (Balesdent et

271 al., 1987, 1993; Skrzypek et al., 2007). Other studies have also reported that C isotope

272 composition of plant detritus gradually changes as polysaccharides (e.g., cellulose,

273 hemicellulose) are preferentially decomposed, leaving a material that is relatively

274 enriched in lignin-derived $\mathrm{C}$ and depleted in ${ }^{13} \mathrm{C}$ (e.g., Benner et al., 1987; Zaccone et

275 al., 2011). Furthermore, microorganisms have been shown to preferentially use ${ }^{14} \mathrm{~N}$

276 during SOM decomposition, thus resulting in ${ }^{15} \mathrm{~N}$ enrichment (Nadelhoffer and Fry,

277 1994). Consequently, our study points to the following decomposition gradient among

278 SOM fractions: mineral associated $>$ intra-microaggregate $>$ intra-macroaggregate $>$

279 free.

280

281

\subsection{DRIFT}

282

283

284

to each other and very different from that of biochar (Fig. 5). The main common

285

features of the spectra of municipal solid waste compost and sewage sludge are the

286

following: a broad band centered near $3350 \mathrm{~cm}^{-1}$ due to $\mathrm{O}-\mathrm{H}$ stretching, two sharp bands

287

at about 2930 and $2850 \mathrm{~cm}^{-1}$ due to aliphatic C-H stretching, various signals between

1650 and $1430 \mathrm{~cm}^{-1}$ derived from amide, amine, and aliphatic groups, and a broad band

centered near $1040 \mathrm{~cm}^{-1}$ due to $\mathrm{C}-\mathrm{O}$ stretching of polysaccharides or polysaccharide-like substances. In contrast, the DRIFT spectrum of biochar is dominated by a very broad band centered at about $3050 \mathrm{~cm}^{-1}$ due to $\mathrm{C}-\mathrm{H}$ aromatic stretch and intense broad 
The DRIFT spectra of the whole soils and the corresponding mineral-associated

295 SOM fractions, which are not affected by the biochar and organic fertilizer factors, exhibit an intense peak at about $3600 \mathrm{~cm}^{-1}$ and three absorption bands at about 1980 ,

2971870 , and $1790 \mathrm{~cm}^{-1}$. These signals, which are much weaker or even absent in the spectra of the free and intra-aggregate SOM fractions, may denote the presence of clay minerals and are typical of soils and soil particle-size fractions (Capriel et al., 1995; Spaccini et al., 2001). Unlike the whole soils and mineral-associated fractions, the DRIFT spectra of the free and aggregate SOM fractions exhibit two aliphatic C-H stretching bands at about $2930 \mathrm{~cm}^{-1}$ and $2850 \mathrm{~cm}^{-1}$, whose intensity tend to decrease with biochar application. The extent of this effect is larger for the free than for the intramacroaggregate pool and is hardly noticeable for the intra-microaggregate fraction. These results are in agreement with those obtained using stable isotopes, and suggest that, after eight months from application, biochar is mainly located outside aggregates, chemically unaltered and unprotected by the mineral matrix, and secondarily occluded within macroaggregates. Our data also suggest that the composition of the mineralassociated SOM fraction is not affected by any of the treatments. Paetsch et al. (2016) also found a high variability in the composition of the particulate SOM isolated from unamended soils and soils amended with urban waste composts and cattle manure, but not in the composition of the mineral-associated fractions. In agreement with previous findings (Plaza et al., 2013; Courtier-Murias et al., 2013), mineral-associated OM 314 predominantly consists of microbial biomass and microbial by-products resulting from the microbial growth, transformation, and degradation processes of organic matter inputs. 
320 Microbial biomass $\mathrm{C}$ is only affected by the organic fertilizer factor (Table 5).

321 Numerous studies available in the literature report positive effects of these kinds of 322 organic fertilizers on microbial biomass (e.g., García-Gil et al., 2000; Marando et al., 323 2011). In a meta-analysis, Kallenbach and Grandy (2011) found that organic 324 amendments increased microbial biomass $\mathrm{C}$ by $36 \%$ relative to inorganic fertilizer 325 across a range of environments and agronomic practices, with the type of amendment 326 having the strongest effects. Due to the amount of $\mathrm{C}$ applied, biochar-treated soils show 327 much lower microbial biomass $\mathrm{C} /$ total organic $\mathrm{C}$ ratios than soils without biochar. No 328 significant main effects and interactions are found for basal respiration and metabolic 329 quotient. These results are indicative of the stability of the $\mathrm{C}$ added with biochar and are 330 in general agreement with the conclusions of previous studies (Kuzyakov et al., 2009, 331 2014). Biochar may add labile compounds mainly derived from incomplete biomass 332 pyrolysis that may stimulate soil microbial growth and activity, but these components 333 are rapidly mineralized and their effects on soil microorganisms are not persistent 334 (Smith et al., 2010).

\section{Conclusions}

Our results provide evidence that, eight months after its application, biochar accumulates mainly in the free SOM fraction, and promotes $\mathrm{C}$ stabilization in organically-fertilized soils through the formation of organo-mineral complexes by

342 intimate interaction between mineral particles and organic inputs. The chemical and 343 structural composition of the organic matter in biochar, compost, and sewage sludge 
344 differs markedly from that of the mineral-associated SOM. However, the composition 345 of the mineral-associated SOM fraction is not affected by any of the treatments 346 compared to the control. This suggests a high degree of microbial transformation of the 347 organic matter stabilized in the mineral-associated fraction of the soils treated with 348 biochar and organic fertilizers. We hypothesize that biochar stimulates the microbial 349 transformation of the relatively more labile organic fractions applied with organic 350 fertilizers and the sorption of the resultant microbial by-products on soil mineral 351 surfaces. Further research is needed to test this hypothesis, as well as the specific 352 mechanisms involved, especially by means of long-term field experimentation. 353 Nonetheless, the data provided in this work strongly support the potential of biochar 354 application as a strategy to sequester $\mathrm{C}$ in soils and fight climate change.

\section{Acknowledgements}

This research was supported by the Spanish Ministry of Economy and 360 Competitiveness (grant AGL2013-48681). José M. Fernández was the recipient of a fellowship from the CSIC JAE-Doc program co-financed by the European Social Fund. 362 Beatrice Giannetta was the recipient of a fellowship from the Lifelong Learning 363 Program, Erasmus Subprogram, financed by the European Commission.

\section{References}

368 Agegnehu, G., Bass, A.M., Nelson, P.N., Bird, M.I., 2016. Benefits of biochar, compost 
and biochar-compost for soil quality, maize yield and greenhouse gas emissions in a tropical agricultural soil. Sci. Total Environ. 543, 295-306

Baldock, J.A., Smernik, R.J., 2002. Chemical composition and bioavailability of thermally altered Pinus resinosa (Red Pine) wood. Org. Geochem. 33, 1093-1109.

Balesdent, J., Guillet, B., Mariotti, A, 1993. Site-related $\delta^{13} \mathrm{C}$ of tree leaves and soil organic matter in a temperate forest. Ecology 74, 1713-1721.

Balesdent, J., Mariotti, A., Guillet, B., 1987. Natural ${ }^{13} \mathrm{C}$ abundance as a tracer for studies of soil organic matter dynamics. Soil Biol. Biochem. 19, 25-30.

Benner, R., Fogel, M.L., Sprague, E.K., Hodson, R.E., 1987. Depletion of C in lignin and its implications for stable carbon isotope studies. Nature 329, 708-710.

Bolan, N.S., Kunhikrishnan, A., Choppala, G.K., Thangarajan, R., Chung, J.W., 2012. Stabilization of carbon in composts and biochars in relation to carbon sequestration and soil fertility. Sci. Total Environ. 424, 264-270.

Capriel, P., Beck, T., Borchert, H., Gronholz, J., Zachmann, G., 1995. Hydrophobicity of the organic matter in arable soils. Soil Biol. Biochem. 27, 1453-1458.

Cernansky, R., 2015. State-of-the-art soil. Nature 517, 258-260.

Chatterjee, S., Santos, F., Abiven, S., Itin, B., Stark, R.E., Bird, J.A., 2012. Elucidating the chemical structure of pyrogenic organic matter by combining magnetic resonance, mid-infrared spectroscopy and mass spectrometry. Org. Geochem. 51, $35-44$.

Courtier-Murias, D., Simpson, A.J., Marzadori, C., Baldoni, G., Ciavatta, C., Fernández, J.M., López-de-Sá, E.G., Plaza, C., 2013. Unraveling the long-term stabilization mechanisms of organic materials in soils by physical fractionation and NMR spectroscopy. Agric. Ecosyst. Environ. 171, 9-18.

Cross, A., Sohi, S.P., 2011. The priming potential of biochar products in relation to 
labile carbon contents and soil organic matter status. Soil Biol. Biochem. 43, 21272134.

De Mendiburu, F. 2014. Agricolae: Statistical Procedures for Agricultural Research. R Package Version 1.2-0, http://CRAN.R-project.org/package=agricolae.

Fernández, J.M., Nieto, A., López-de-Sá, E.G., Gascó, G., Méndez, A., Plaza, C., 2014a. Carbon dioxide emissions from semi-arid soils amended with biochar alone or combined with mineral and organic fertilizers. Sci. Total Environ. 482-483, 1-7.

Fernández, J.M., López-de-Sá, E.G., Polo, A., Plaza, C., 2014b. Short-term stabilization of organic matter in physically, chemically, and biochemically protected pools in soils amended with municipal wastes. CLEAN - Soil Air Water 42, 487-493.

García-Gil, J.C., Plaza, C., Soler-Rovira, P., Polo, A., 2000. Long-term effects of municipal solid waste compost application on soil enzyme activities and microbial biomass. Soil Biol. Biochem. 32, 1907-1913.

Golchin, A., Oades, J.M., Skjemstad, J.O., Clarke, P., 1994. Study of free and occluded particulate organic matter in soils by solid state ${ }^{13} \mathrm{C}$ CP/MAS NMR spectroscopy and scanning electron microscopy. Aust. J. Soil Res. 32, 285-309.

Harris, D., Horwath, W.R., van Kessel, C., 2001. Acid fumigation of soils to remove carbonates prior to total organic carbon or carbon-13 isotopic analysis. Soil Sci. Soc. Am. J. 65, 1853-1856.

Herath, H.M.S.K., Camps-Arbestain, M., Hedley, M., Van Hale, R., Kaal, J., 2014. Fate of biochar in chemically- and physically-defined soil organic carbon pools. Org. Geochem. 73, 35-46.

Jeffery, S., Verheijen, F.G.A., van der Velde, M., Bastos, A.C., 2011. A quantitative review of the effects of biochar application to soils on crop productivity using metaanalysis. Agric. Ecosyst. Environ. 144, 175-187. 
Jones, D.L., Murphy, D.V., Khalid, M., Ahmad, W., Edwards-Jones, G., DeLuca, T.H., 2011. Short-term biochar-induced increase in soil $\mathrm{CO}_{2}$ release is both biotically and abiotically mediated. Soil Biol. Biochem. 43, 1723-1731.

Kallenbach, C., Grandy, A.S., 2011. Controls over soil microbial biomass responses to carbon amendments in agricultural systems: A meta-analysis. Agric. Ecosyst. Environ. 144, 241-252.

Kuzyakov, Y., Subbotina, I., Chen, H.Q., Bogomolova, I., Xu, X.L., 2009. Black carbon decomposition and incorporation into soil microbial biomass estimated by $\mathrm{C}-14$ labeling. Soil Biol. Biochem. 41, 210-219.

Kuzyakov, Y., Bogomolova, I., Glaser, B., 2014. Biochar stability in soil: decomposition during eight years and transformation as assessed by compoundspecific 14C analysis. Soil Biol. Biochem. 70, 229-236.

Lehmann, J., 2007. A handful of carbon. Nature 447, 143-144.

Lehmann, J., Joseph, S., 2015. Biochar for Environmental Management: Science and Technology, $2^{\text {nd }}$ Edition. Earthscan, London, UK.

Liang, B.Q., Lehmann, J., Sohi, S.P., Thies, J.E., O'Neill, B., Trujillo, L., Gaunt, J., Solomon, D., Grossman, J., Neves, E.G., Luizão, F.J., 2010. Black carbon affects the cycling of non-black carbon in soil. Org. Geochem. 41, 206-213.

Lu, W., Ding, W., Zhang, J., Li, Y., Luo, J., Bolan, N., Xie, Z., 2014. Biochar suppressed the decomposition of organic carbon in a cultivated sandy loam soil: a negative priming effect. Soil Biol. Biochem. 76, 12-21.Luo, Y., Durenkamp, M., De Nobili, M., Lin, Q., Brookes, P.C., 2011. Short term soil priming effects and the mineralisation of biochar following its incorporation to soils of different $\mathrm{pH}$. Soil Biol. Biochem. 43, 2304-2314.

Marando, G., Jiménez, P., Hereter, A., Julià, M., Ginovart, M., Bonmatí, M., 2011. 
Effects of thermally dried and composted sewage sludges on the fertility of residual

$445 \quad$ soils from limestone quarries. Appl. Soil Ecol. 49, 234-241.

446 Masiello, C.A., Chen, Y., Gao, X., Liu, S., Cheng, H.Y., Bennett, M.R., Rudgers, J.A.,

447 Wagner, D. S., Zygourakis, K., Silberg, J.J., 2013. Biochar and microbial signaling:

448 production conditions determine effects on microbial communication. Environ. Sci.

449 Technol. 47, 11496-11503.

450 Moreno-Jiménez, E., Fernández, J.M., Puschenreiter, M., Williams, P.N., Plaza, C.,

451 2016. Availability and transfer to grain of $\mathrm{As}, \mathrm{Cd}, \mathrm{Cu}, \mathrm{Ni}, \mathrm{Pb}$ and $\mathrm{Zn}$ in a barley

452 agri-system: Impact of biochar, organic and mineral fertilizers. Agric. Ecosyst.

$453 \quad$ Environ. 219, 171-178.

454 Nadelhoffer, K.J., Fry, B., 1994. N isotope studies in forested ecosystems. In: Lajtha,

455 K., Michener, R.H. (Eds.), Stable isotopes in ecology and environmental science.

$456 \quad$ Blackwell, Oxford, UK, pp. 22-44.

457 Ngo, P.T, Rumpel, C., Ngo, A. Q.A., Alexis, M., Velásquez Vargas, G., Mora Gil,

458 M.L., Dang, D.K., Jouquet, P., 2013. Biological and chemical reactivity and

459 phosphorus forms of buffalo manure compost, vermicompost and their mixture with

460 biochar. Bioresour. Technol. 148, 401-407.

461 Ngo, P.T, Rumpel, C., Thu, T.D., Henry-des-Tureaux, T., Dang, D.K., Jouquet, P.,

462 2014. Use of organic substrates for increasing soil organic matter quality and

463 carbon sequestration of tropical degraded soil: a 3-year mesocosms experiment.

$464 \quad$ Carbon Manag. 5, 155-168.

465 Ngo, P.T., Rumpel, C., Janeaud, J.L., Dang, D.K., Jouquet, P., 2016. Mixing of biochar

466 with organic amendments reduces carbon removal after field exposure under

$467 \quad$ tropical conditions. Ecol. Eng. 91, 378-380.

468 Paetsch, L., Mueller, C.W., Rumpel, C., Houot, S., Kögel-Knabner, I., 2016. Urban 
waste composts enhance $\mathrm{OC}$ and $\mathrm{N}$ stocks after long-term amendment but do not

470 alter organic matter composition. Agric. Ecosyst. Environ. 223, 211-222.

471 Piccolo, A., 2001. The supramolecular structure of humic substances. Soil Sci.166, $472 \quad 810-832$.

473 Plaza, C., Courtier-Murias, D., Fernández, J.M., Polo, A., Simpson, A.J., 2013. 474 Physical, chemical, and biochemical mechanisms of soil organic matter stabilization 475 under conservation tillage systems: a central role for microbes and microbial by476 products in C sequestration. Soil Biol. Biochem. 57, 124-134.

477 Plaza, C., Fernández, J.M., Pereira, E.I.P., Polo, A., 2012. A comprehensive method for 478 fractionating soil organic matter not protected and protected from decomposition by 479 physical and chemical mechanisms. CLEAN-Soil Air Water 40, 134-139.

R Core Team, 2014. R: A Language and Environment for Statistical Computing. R

Schnitzer, M., Monreal, C.M., 2011. Chapter three - Quo Vadis soil organic matter research? A biological link to the chemistry of humification. In: Sparks, D.L. (Ed.), Advances in Agronomy. Academic Press, pp. 143-217.

Senesi, N., Plaza, C., Brunetti, G., Polo, A., 2007. A comparative survey of recent results on humic-like fractions in organic amendments and effects on native soil humic substances. Soil Biol. Biochem. 39, 1244-1262.

Singh, B.P., Cowie, A.L., 2014. Long-term influence of biochar on native organic carbon mineralisation in a low-carbon clayey soil. Sci. Rep. 4, 3687.

Six, J., Conant, R.T., Paul, E.A., Paustian, K., 2002a. Stabilization mechanisms of soil organic matter: implications for C-saturation of soils. Plant Soil 241, 155-176.

Six, J., Callewaert, P., Lenders, S., De Gryze, S., Morris, S.J., Gregorich, E.G., Paul, E.A., Paustian, K., 2002b. Measuring and understanding carbon storage in 
afforested soils by physical fractionation. Soil Sci. Soc. Am. J. 66, 1981-1987.

495

496

497

498

499

500

501

502

503

504

505

506

507

508

509

510

511

512

513

514

515

516

517

518

Six, J., Elliott, E.T., Paustian, K., 2000. Soil macroaggregate turnover and microaggregate formation: a mechanism for $\mathrm{C}$ sequestration under no-tillage agriculture. Soil Biol. Biochem. 32, 2099-2103.

Skrzypek, G., Kałużny, A., Wojtuń, B., Jędryseket , M.-O., 2007. The carbon stable isotopic composition of mosses: a record of temperature variation. Org. Geochem. $38,1770-1781$.

Smith, J.L., Collins, H.P., Bailey, V.L., 2010. The effect of young biochar on soil respiration. Soil Biol. Biochem. 42, 2345-2347

Sohi, S.P., Mahieu, N., Arah, J.R.M., Powlson, D.S., Madari, B., Gaunt, J.L., 2001. A procedure for isolating soil organic matter fractions suitable for modeling. Soil Sci. Soc. Am. J. 65, 1121-1128.

Soil Survey Staff, 2014. Keys to Soil Taxonomy, 12th ed. USDA-Natural Resources Conservation Service, Washington, DC.

Spaccini, R., Piccolo, A., Haberhauer, G., Stemmer, M., Gerzabek, M.H., 2001. Decomposition of maize straw in three European soils as revealed by DRIFT spectra of soil particle fractions. Geoderma, 99, 245-260.

Vance, E.D., Brookes, P.C., Jenkinson, D.S., 1987. An extraction method for measuring soil microbial biomass C. Soil Biol. Biochem. 19, 703-707.

Von Lützow, M., Kögel-Knabner, I., Ekschmitt, K., Matzner, E., Guggenberger, G., Marschner, B., Flessa, H., 2006. Stabilization of organic matter in temperate soils: mechanisms and their relevance under different soil conditions - a review. Eur. J. Soil Sci. 57, 426-445.

Wardle, D.A., Nilsson, M.C., Zackrisson, O., 2008. Fire-derived charcoal causes loss of forest humus. Science 320, 629. 
519 Weng, Z.H., Van Zwieten, L., Singh, B.P., Kimber, S., Morris, S., Cowie, A., 520 Macdonald, L.M., 2015. Plant-biochar interactions drive the negative priming of 521 soil organic carbon in an annual ryegrass field system. Soil Biol. Biochem. 90, 111$522 \quad 121$

523 Zaccone, C., Casiello, G., Longobardi, F., Bragazza, L., Sacco, A., Miano, T.M., 2011. 524 Evaluating the 'conservative' behaviour of stable isotopic ratios $\left(\delta^{13} \mathrm{C}, \delta^{15} \mathrm{~N}\right.$, and $\left.525 \quad \delta^{18} \mathrm{O}\right)$ in humic acids and their reliability as paleoenvironmental proxies along a peat 526 sequence. Chem. Geol. 285, 124-132.

527 Zimmerman, A.R., Gao, B., Ahn, M.-Y., 2011. Positive and negative carbon 528 mineralization priming effects among a variety of biochar-amended soils. Soil Biol. $529 \quad$ Biochem. 43, 1169-1179.

530 


\section{$531 \quad$ Figure captions}

532 Fig. 1. Free, intra-macroaggregate, intra-microaggregate, and mineral-associated organic C content of soils either unfertilized (UN), amended with municipal solid waste

534 compost (MC), or amended with sewage sludge (SS), without or with biochar (BC).

535 Error bars indicate pooled standard error. Different letters indicate statistically

536 significant differences according to Fisher's LSD test at the 0.05 level.

537 Fig. 2. Free, intra-macroaggregate, intra-microaggregate, and mineral-associated N 538 content of soils either unamended (UN), amended with municipal solid waste compost 539 (MC), or amended with sewage sludge (SS), without or with biochar (BC). Error bars 540 indicate pooled standard error. Different letters indicate statistically significant 541 differences according to Fisher's LSD test at the 0.05 level.

542 Fig. 3. Free, intra-macroaggregate, intra-microaggregate, and mineral-associated C/N 543 ratio of soils either unamended (UN), amended with municipal solid waste compost 544 (MC), or amended with sewage sludge (SS), without or with biochar (BC). Error bars 545 indicate pooled standard error. Different letters indicate statistically significant 546 differences according to Fisher's LSD test at the 0.05 level.

547 Fig. 4. Relationship between stable isotope signatures $\left(\delta^{13} \mathrm{C}\right.$ and $\left.\delta^{15} \mathrm{~N}\right)$ and $\mathrm{C} / \mathrm{N}$ ratios of 548 untreated (control) whole soil (WS) and corresponding organic matter fractions (FR, 549 free; MA, intra-macroaggregate; MI, intra-microaggregate; and MIN, mineral550 associated).

551 Fig. 5. Diffuse reflectance infrared Fourier transform (DRIFT) spectra of biochar, 552 municipal solid waste compost, sewage sludge, and whole soils and soil organic matter 553 fractions (i.e., free, intra-macroaggregate, intra-microaggregate, and mineral-associated $554 \mathrm{OM}$ ), as affected by amendment with municipal solid waste compost (MC) or sewage 555 sludge (SS), with or without biochar (BC). 
Table 1

Chemical properties (mean \pm standard error of three laboratory replicates) of the soil, biochar, municipal solid waste compost, and sewage sludge used in this work (data from Fernández et al., 2014)

\begin{tabular}{lcccc}
\hline Property & Soil & Biochar & Compost & Sewage sludge \\
\hline $\mathrm{pH}$ & $8.80 \pm 0.03$ & $10.06 \pm 0.01$ & $6.79 \pm 0.01$ & $7.30 \pm 0.03$ \\
$\mathrm{EC}\left(\mathrm{dS} \mathrm{m}^{-1}\right)$ & $0.11 \pm 0.00$ & $2.4 \pm 0.0$ & $10.8 \pm 1.0$ & $2.2 \pm 0.2$ \\
Total organic C $\left(\mathrm{g} \mathrm{kg}^{-1}\right)$ & $10.0 \pm 0.1$ & $597 \pm 31$ & $295 \pm 3$ & $277 \pm 4$ \\
Inorganic C $\left(\mathrm{g} \mathrm{kg}^{-1}\right)$ & $5.9 \pm 0.1$ & $14.7 \pm 1.6$ & $9.4 \pm 3.8$ & $9.3 \pm 4.0$ \\
Total N $\left(\mathrm{g} \mathrm{kg}^{-1}\right)$ & $1.2 \pm 0.0$ & $4.1 \pm 0.6$ & $16.0 \pm 0.2$ & $43.9 \pm 0.5$ \\
$\mathrm{C} / \mathrm{N}$ & $8.3 \pm 0.1$ & $151 \pm 18$ & $18.45 \pm 0.02$ & $6.31 \pm 0.09$ \\
$\mathrm{P}\left(\mathrm{g} \mathrm{kg}^{-1}\right)$ & $0.006 \pm 0.001^{\mathrm{a}}$ & $2.0 \pm 0.2$ & $3.1 \pm 0.2$ & $19.2 \pm 0.8$ \\
$\mathrm{~K}\left(\mathrm{~g} \mathrm{~kg}^{-1}\right)$ & $0.21 \pm 0.02^{\mathrm{a}}$ & $9.1 \pm 0.7$ & $6.9 \pm 0.2$ & $3.6 \pm 0.1$ \\
$\mathrm{Ca}\left(\mathrm{g} \mathrm{kg}^{-1}\right)$ & $2.93 \pm 0.14^{\mathrm{a}}$ & $52.4 \pm 4.0$ & $38.2 \pm 1.6$ & $30.3 \pm 0.8$ \\
$\mathrm{Mg}\left(\mathrm{g} \mathrm{kg}^{-1}\right)$ & $0.25 \pm 0.02^{\mathrm{a}}$ & $3.5 \pm 0.3$ & $3.5 \pm 0.2$ & $6.2 \pm 0.1$ \\
$\mathrm{Na}\left(\mathrm{g} \mathrm{kg}^{-1}\right)$ & $0.069 \pm 0.006^{\mathrm{a}}$ & $0.3 \pm 0.0$ & $4.5 \pm 0.2$ & $0.7 \pm 0.0$ \\
& & & & \\
\hline
\end{tabular}

EC, electrical conductivity.

${ }^{a}$ Available content. 
Table 2

Analysis of variance ( $p$-values)

\begin{tabular}{|c|c|c|c|c|}
\hline & \multicolumn{3}{|c|}{ Two-way ANOVA } & \multirow{2}{*}{$\frac{\text { One-way ANOVA }}{\text { Treatment }}$} \\
\hline & Biochar & Organic fertilizer & Biochar $\times$ Organic fertilizer & \\
\hline Total organic $\mathrm{C}$ & $<0.001 * * *$ & $0.006 * *$ & 0.327 & $<0.001 * * *$ \\
\hline Free organic $\mathrm{C}$ & $<0.001 * * *$ & 0.374 & 0.274 & $<0.001 * * *$ \\
\hline Intra-macroaggregate organic $\mathrm{C}$ & 0.465 & $0.035^{*}$ & 0.656 & 0.142 \\
\hline Intra-microaggregate organic $\mathrm{C}$ & 0.814 & 0.214 & 0.084 & 0.160 \\
\hline Mineral-associated organic C & $0.004 * *$ & $<0.001 * * *$ & $0.010^{*}$ & $<0.001 * * *$ \\
\hline Total N & 0.108 & $<0.001 * * *$ & 0.343 & $0.002 * *$ \\
\hline Free organic $\mathrm{N}$ & $0.002 * *$ & $<0.001 * * *$ & 0.232 & $<0.001 * * *$ \\
\hline Intra-macroaggregate $\mathrm{N}$ & 0.593 & $0.026^{*}$ & 0.635 & 0.119 \\
\hline Intra-microaggregate $\mathrm{N}$ & 0.254 & 0.345 & 0.103 & 0.173 \\
\hline Mineral-associated N & $0.009 * *$ & $0.028 *$ & $0.035^{*}$ & $0.005^{* *}$ \\
\hline Total organic $\mathrm{C} / \mathrm{N}$ & $<0.001 * * *$ & 0.140 & 0.100 & $<0.001 * * *$ \\
\hline Free organic $\mathrm{C} / \mathrm{N}$ & $<0.001 * * *$ & $<0.001 * * *$ & $0.003 * *$ & $<0.001 * * *$ \\
\hline Intra-macroaggregate $\mathrm{C} / \mathrm{N}$ & $0.002 * *$ & $0.007 * *$ & 0.248 & $0.002 * *$ \\
\hline Intra-microaggregate $\mathrm{C} / \mathrm{N}$ & $<0.001 * * *$ & $0.002 * *$ & 0.497 & $<0.001 * * *$ \\
\hline Mineral-associated C/N & 0.062 & 0.1658 & $0.002 * *$ & $0.004 * *$ \\
\hline Microbial biomass $\mathrm{C}$ & 0.212 & $0.010^{*}$ & 0.078 & $0.015^{*}$ \\
\hline Microbial biomass $\mathrm{C} /$ total organic $\mathrm{C}$ & $<0.001 * * *$ & 0.051 & $0.044 *$ & $<0.001 * * *$ \\
\hline Basal respiration & 0.811 & 0.057 & 0.680 & 0.230 \\
\hline Metabolic quotient & 0.336 & 0.863 & 0.105 & 0.313 \\
\hline
\end{tabular}

$*, * *$, and $* * *$, significant at the $0.05,0.01$, and 0.001 probability level, respectively. 


\section{Table 3}

Total organic $\mathrm{C}$ content, total $\mathrm{N}$, and $\mathrm{C} / \mathrm{N}$ ratio (mean \pm pooled standard error) of soils either unamended (UN), or amended with municipal solid waste compost (MC) or sewage sludge (SS), without or with biochar (BC)

\begin{tabular}{lccc}
\hline & Total organic $\mathrm{C}\left(\mathrm{g} \mathrm{kg}^{-1}\right)$ & Total N $\left(\mathrm{g} \mathrm{kg}^{-1}\right)$ & $\mathrm{C} / \mathrm{N}$ \\
\hline $\mathrm{UN}$ & $11.8 \pm 0.7 \mathrm{~d}$ & $1.10 \pm 0.05 \mathrm{c}$ & $10.7 \pm 0.6 \mathrm{c}$ \\
$\mathrm{MC}$ & $14.2 \pm 0.7 \mathrm{c}$ & $1.31 \pm 0.05 \mathrm{ab}$ & $10.8 \pm 0.6 \mathrm{c}$ \\
$\mathrm{SS}$ & $12.7 \pm 0.7 \mathrm{~cd}$ & $1.19 \pm 0.05 \mathrm{bc}$ & $10.6 \pm 0.6 \mathrm{c}$ \\
$\mathrm{BC}+\mathrm{UN}$ & $19.8 \pm 0.7 \mathrm{~b}$ & $1.08 \pm 0.05 \mathrm{c}$ & $18.6 \pm 0.6 \mathrm{a}$ \\
$\mathrm{BC}+\mathrm{MC}$ & $22.6 \pm 0.7 \mathrm{a}$ & $1.42 \pm 0.05 \mathrm{a}$ & $15.9 \pm 0.6 \mathrm{~b}$ \\
$\mathrm{BC}+\mathrm{SS}$ & $22.7 \pm 0.7 \mathrm{a}$ & $1.33 \pm 0.05 \mathrm{ab}$ & $17.2 \pm 0.6 \mathrm{ab}$ \\
\hline
\end{tabular}

Different letters indicate statistically significant differences according to Fisher's LSD test at the 0.05 level. 


\section{Table 4}

$\delta^{13} \mathrm{C}$ and $\delta^{15} \mathrm{~N}$ (mean \pm standard deviation) of biochar, municipal solid waste compost, and whole soils and soil organic matter fractions (i.e., free, intra-macroaggregate, intra-microaggregate, and mineral-associated), as affected by amendment with municipal solid waste compost (MC), with or without biochar (BC).

\begin{tabular}{|c|c|c|}
\hline & $\delta^{13} \mathrm{C}$ & $\delta^{15} \mathrm{~N}$ \\
\hline Biochar & $-26.65 \pm 0.06$ & $2.32 \pm 0.27$ \\
\hline Municipal solid waste compost & $-25.13 \pm 0.07$ & $6.63 \pm 0.12$ \\
\hline \multicolumn{3}{|l|}{ Whole soils } \\
\hline UN & $-24.44 \pm 0.14$ & $7.79 \pm 0.15$ \\
\hline $\mathrm{MC}$ & $-20.51 \pm 0.23$ & $6.03 \pm 0.17$ \\
\hline $\mathrm{BC}+\mathrm{UN}$ & $-23.08 \pm 0.04$ & $5.54 \pm 0.25$ \\
\hline $\mathrm{BC}+\mathrm{MC}$ & $-22.61 \pm 0.02$ & $5.83 \pm 0.47$ \\
\hline \multicolumn{3}{|l|}{ Free organic matter } \\
\hline $\mathrm{UN}$ & $-23.34 \pm 0.02$ & $4.76 \pm 0.19$ \\
\hline $\mathrm{MC}$ & $-24.24 \pm 0.03$ & $5.25 \pm 0.18$ \\
\hline $\mathrm{BC}+\mathrm{UN}$ & $-25.95 \pm 0.13$ & $3.42 \pm 0.13$ \\
\hline $\mathrm{BC}+\mathrm{MC}$ & $-25.80 \pm 0.10$ & $3.91 \pm 0.24$ \\
\hline \multicolumn{3}{|c|}{ Intra-macroaggregate organic matter } \\
\hline UN & $-24.28 \pm 0.01$ & $5.03 \pm 0.16$ \\
\hline $\mathrm{MC}$ & $-24.69 \pm 0.04$ & $4.62 \pm 0.03$ \\
\hline $\mathrm{BC}+\mathrm{UN}$ & $-24.98 \pm 0.04$ & $4.60 \pm 0.24$ \\
\hline $\mathrm{BC}+\mathrm{MC}$ & $-25.01 \pm 0.07$ & $4.62 \pm 0.09$ \\
\hline \multicolumn{3}{|c|}{ Intra-microaggregate organic matter } \\
\hline $\mathrm{UN}$ & $-24.61 \pm 0.03$ & $5.42 \pm 0.12$ \\
\hline $\mathrm{MC}$ & $-24.84 \pm 0.03$ & $5.37 \pm 0.14$ \\
\hline $\mathrm{BC}+\mathrm{UN}$ & $-24.93 \pm 0.02$ & $5.40 \pm 0.09$ \\
\hline $\mathrm{BC}+\mathrm{MC}$ & $-24.98 \pm 0.06$ & $5.24 \pm 0.24$ \\
\hline \multicolumn{3}{|l|}{ Mineral-associated organic matter } \\
\hline $\mathrm{UN}$ & $-25.25 \pm 0.13$ & $8.34 \pm 0.12$ \\
\hline $\mathrm{MC}$ & $-25.10 \pm 0.07$ & $8.36 \pm 0.11$ \\
\hline $\mathrm{BC}+\mathrm{UN}$ & $-25.20 \pm 0.03$ & $8.39 \pm 0.00$ \\
\hline $\mathrm{BC}+\mathrm{MC}$ & $-25.28 \pm 0.16$ & $8.04 \pm 0.22$ \\
\hline
\end{tabular}




\section{Table 5}

Microbial biomass $\mathrm{C}$ content, microbial biomass $\mathrm{C} /$ total organic $\mathrm{C}$ ratio, basal respiration, and metabolic quotient (mean \pm pooled standard error) of soils either unamended (UN), or amended with municipal solid waste compost (MC) or with sewage sludge (SS), without or with biochar (BC)

\begin{tabular}{lcccc}
\hline & $\begin{array}{c}\text { Microbial biomass } \\
\mathrm{C}\left(\mathrm{mg} \mathrm{kg}^{-1}\right)\end{array}$ & $\begin{array}{c}\text { Microbial biomass } \\
\mathrm{C} / \text { Total organic } \mathrm{C} \\
(\%)\end{array}$ & $\begin{array}{c}\text { Basal respiration } \\
\left(\mathrm{mg} \mathrm{CO}_{2}-\mathrm{C} \mathrm{kg}^{-1}\right. \\
\left.\text { day }^{-1}\right)\end{array}$ & $\begin{array}{c}\text { Metabolic quotient } \\
\left(\mathrm{mg} \mathrm{CO}_{2}-\mathrm{C} \mathrm{g}^{-1}\right. \\
\text { microbial biomass } \\
\left.\mathrm{C} \mathrm{day}^{-1}\right)\end{array}$ \\
\hline $\mathrm{UN}$ & $315 \pm 40 \mathrm{c}$ & $2.67 \pm 0.23 \mathrm{~b}$ & $30.6 \pm 5.0 \mathrm{a}$ & $97 \pm 14.4 \mathrm{a}$ \\
$\mathrm{MC}$ & $546 \pm 40 \mathrm{a}$ & $3.85 \pm 0.23 \mathrm{a}$ & $39.9 \pm 5.0 \mathrm{a}$ & $73 \pm 14.4 \mathrm{a}$ \\
$\mathrm{SS}$ & $458 \pm 40 \mathrm{ab}$ & $3.56 \pm 0.23 \mathrm{a}$ & $41.5 \pm 5.0 \mathrm{a}$ & $92 \pm 14.4 \mathrm{a}$ \\
$\mathrm{BC}+\mathrm{UN}$ & $361 \pm 40 \mathrm{bc}$ & $1.85 \pm 0.23 \mathrm{c}$ & $30.1 \pm 5.0 \mathrm{a}$ & $83 \pm 14.4 \mathrm{a}$ \\
$\mathrm{BC}+\mathrm{MC}$ & $399 \pm 40 \mathrm{bc}$ & $1.80 \pm 0.23 \mathrm{c}$ & $45.9 \pm 5.0 \mathrm{a}$ & $122 \pm 14.4 \mathrm{a}$ \\
$\mathrm{BC}+\mathrm{SS}$ & $431 \pm 40 \mathrm{abc}$ & $1.92 \pm 0.23 \mathrm{c}$ & $39.0 \pm 5.0 \mathrm{a}$ & $92 \pm 14.4 \mathrm{a}$ \\
\hline $\mathrm{Differ}$ & & & & 0 \\
\hline
\end{tabular}

Different letters indicate statistically significant differences according to Fisher's LSD test at the 0.05 level. 

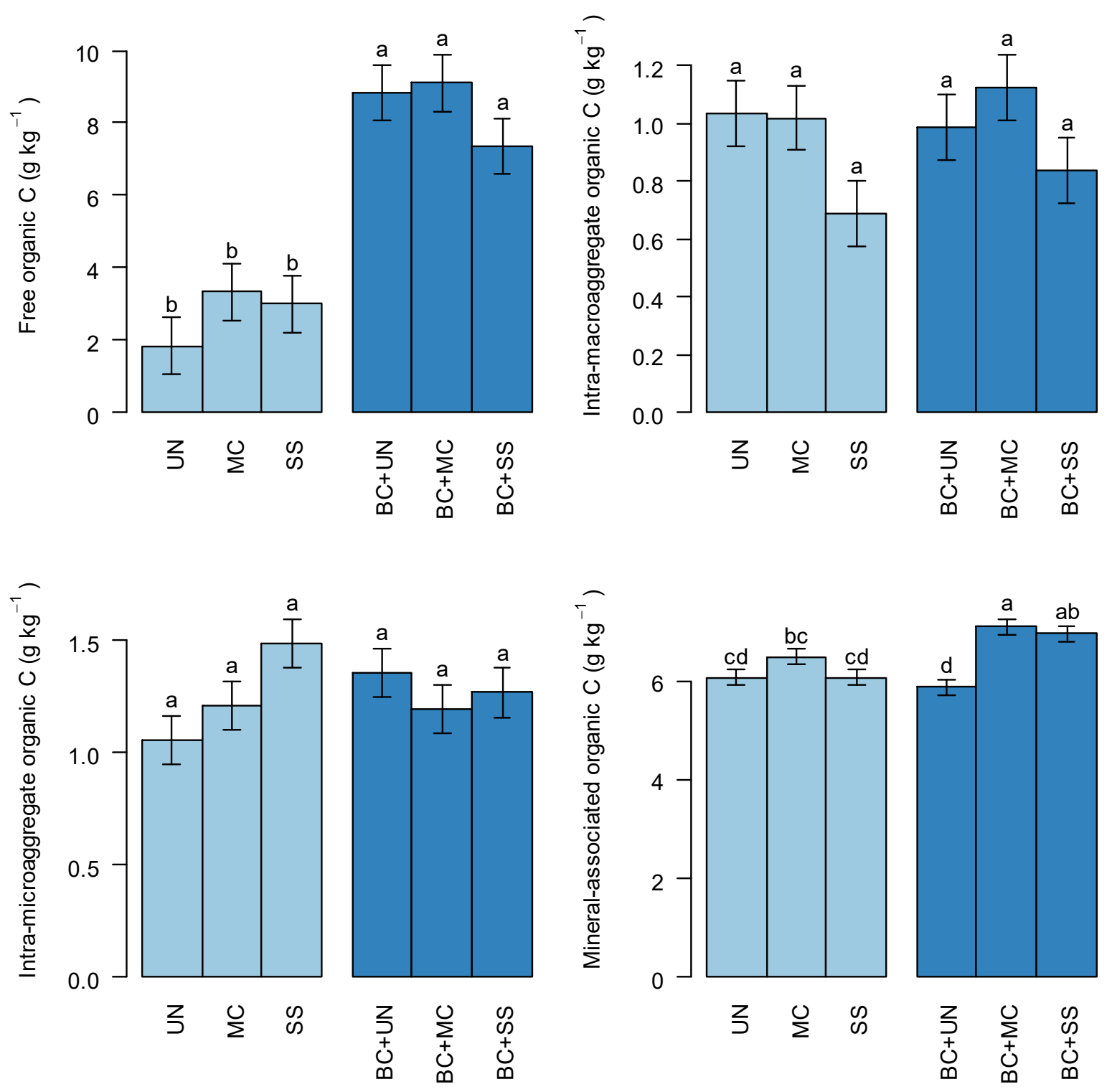

Fig. 1. 

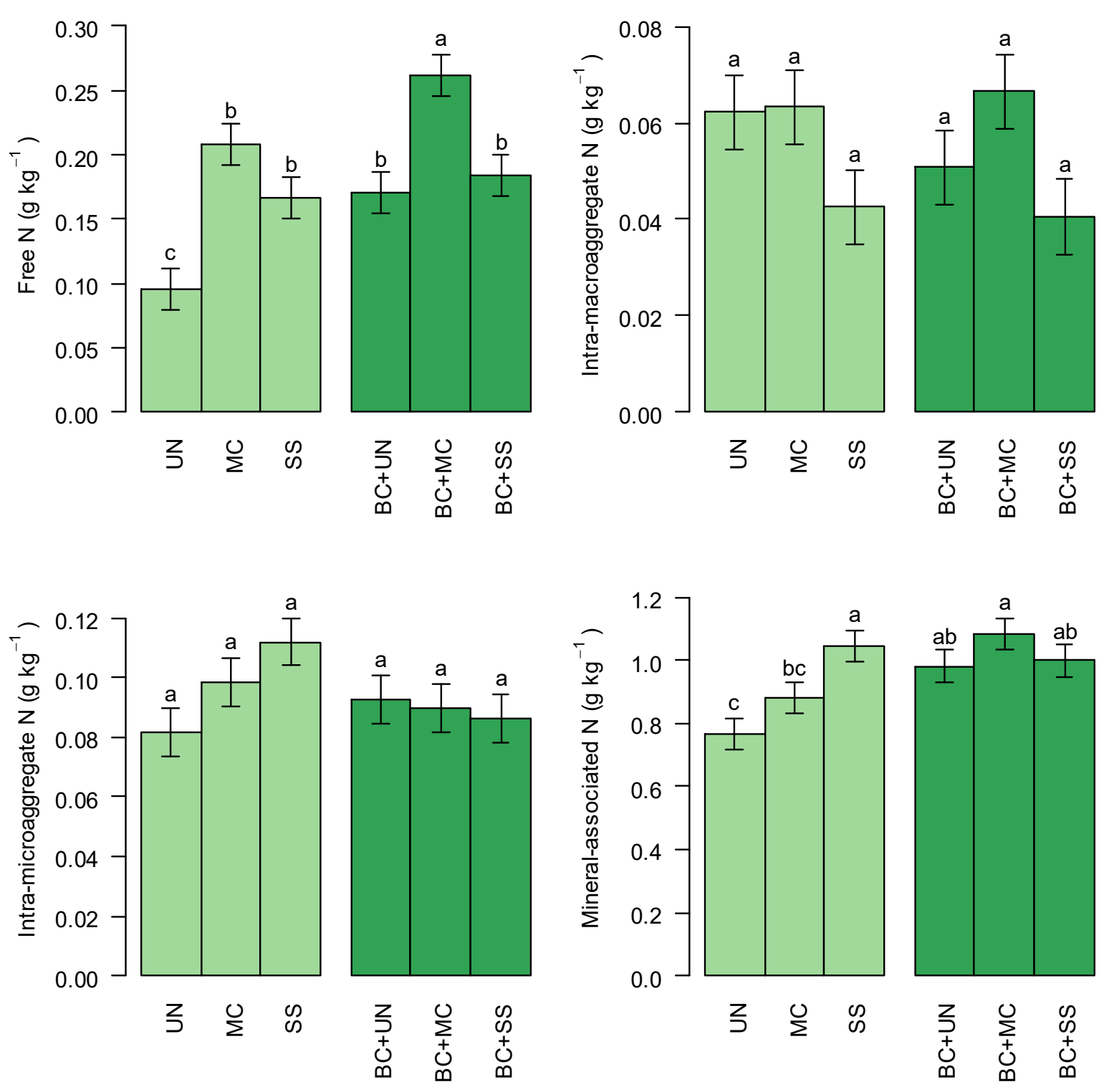

Fig. 2. 

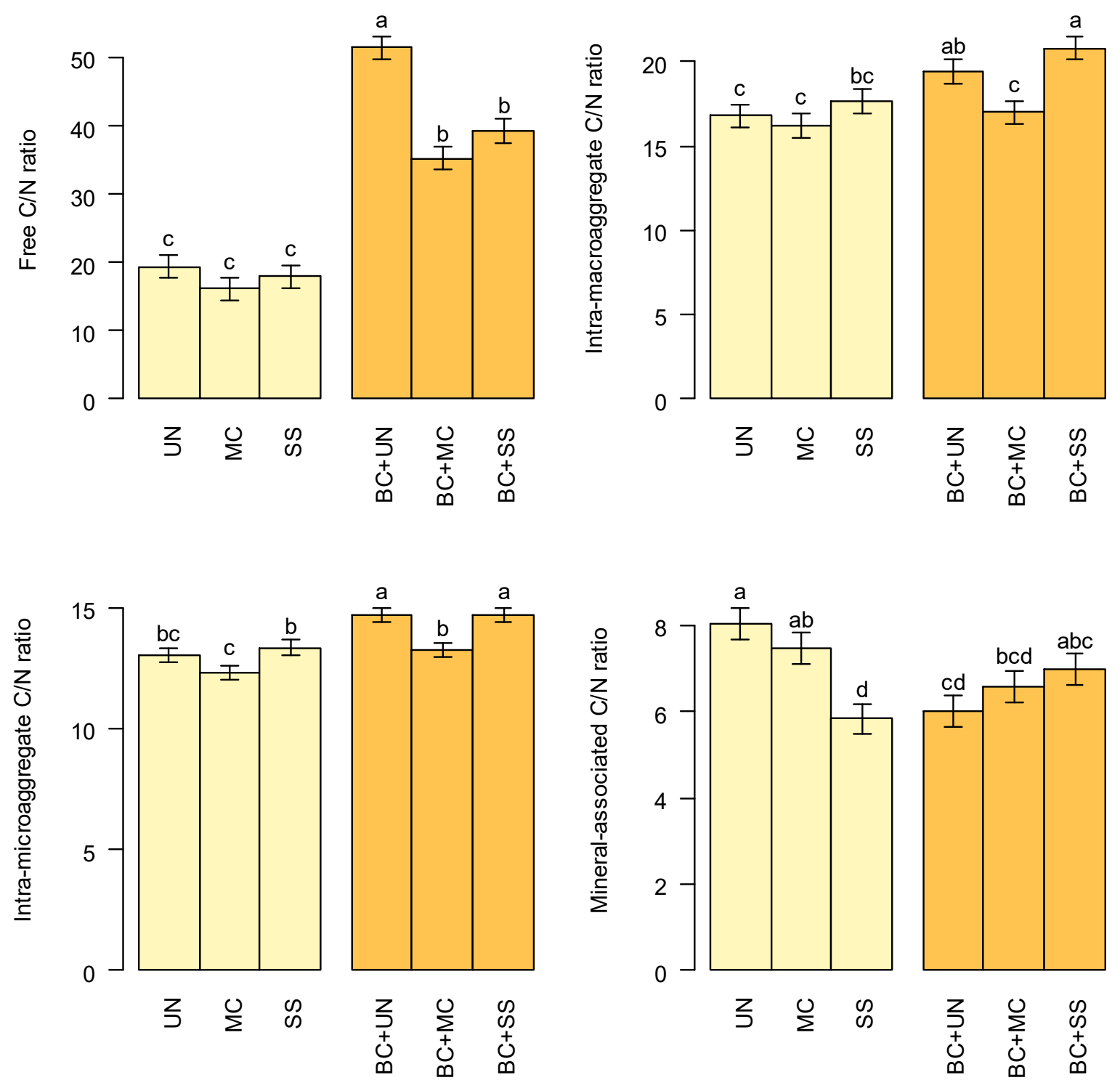

Fig. 3. 

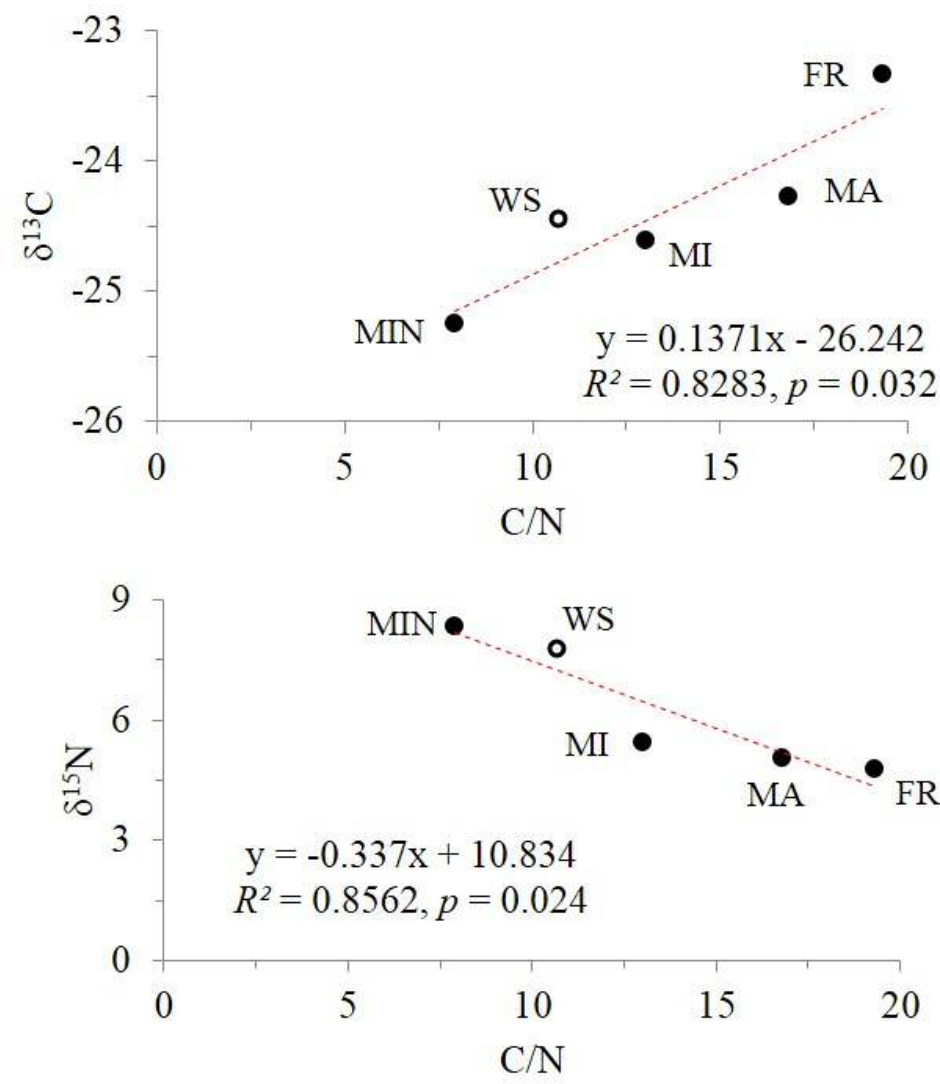

Fig. 4. 

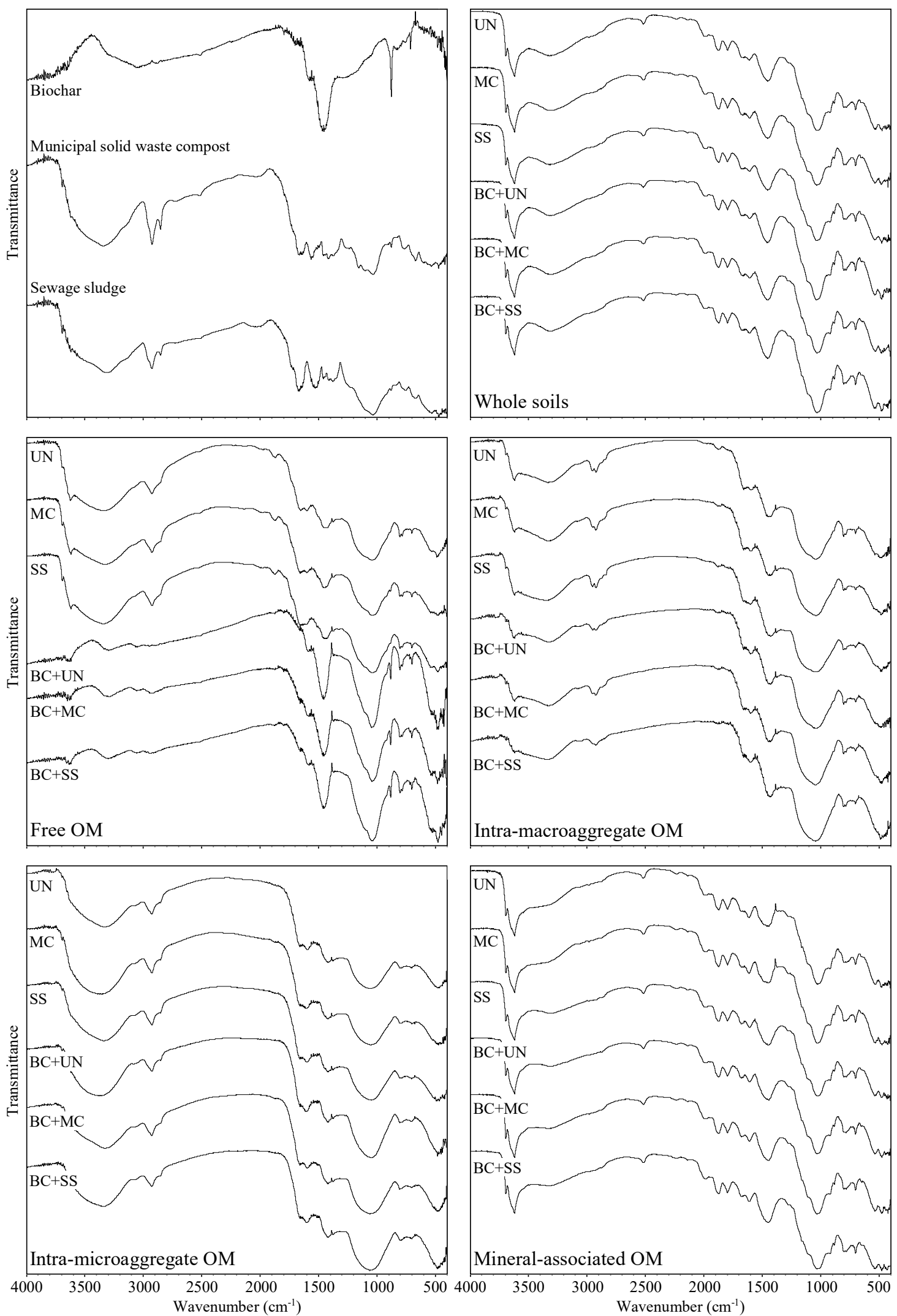

Fig. 5. 